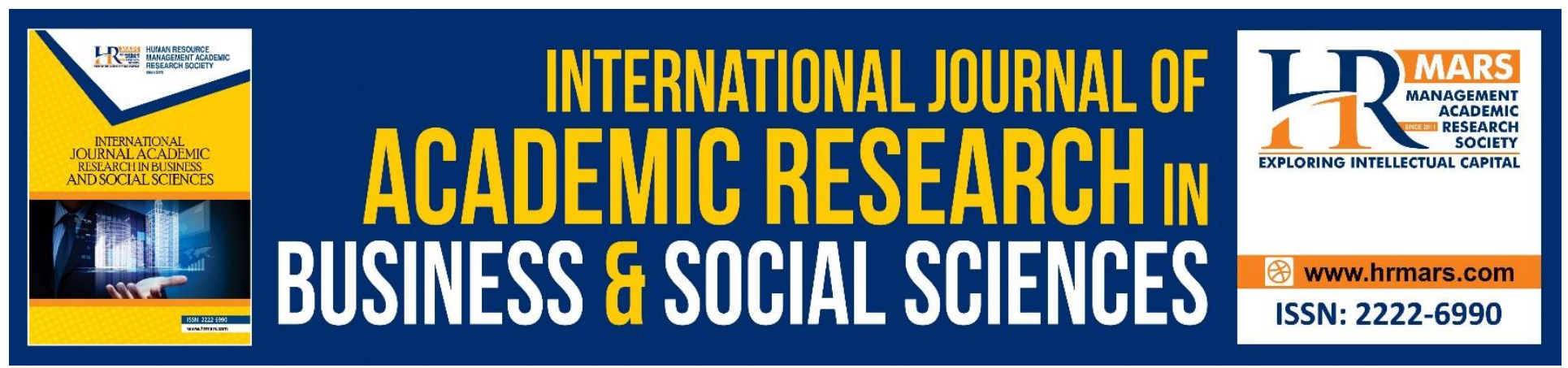

\title{
Regulating the Protection and Rehabilitation of Victims of Internet Child Pornography in Malaysia
}

\author{
Najwa Rosli, Nabilah Hani Ahmad Zubaidi, Farah Nini Dusuki
}

To Link this Article: http://dx.doi.org/10.6007/IJARBSS/v9-i5/5887

DOI: $10.6007 /$ IJARBSS/v9-i5/5887

Received: 01 March 2019, Revised: 28 March 2019, Accepted: 21 April 2019

Published Online: 25 May 2019

In-Text Citation: (Rosli, Zubaidi, \& Dusuki, 2019)

To Cite this Article: Rosli, N., Zubaidi, N. H. A., \& Dusuki, F. N. (2019). Regulating the Protection and

Rehabilitation of Victims of Internet Child Pornography in Malaysia. International Journal of Academic Research Business and Social Sciences, 9(5), 450-469.

\section{Copyright: (C) 2019 The Author(s)}

Published by Human Resource Management Academic Research Society (www.hrmars.com)

This article is published under the Creative Commons Attribution (CC BY 4.0) license. Anyone may reproduce, distribute, translate and create derivative works of this article (for both commercial and non-commercial purposes), subject to full attribution to the original publication and authors. The full terms of this license may be seen

at: http://creativecommons.org/licences/by/4.0/legalcode

Vol. 9, No. 5, 2019, Pg. 450 - 469

http://hrmars.com/index.php/pages/detail/IJARBSS

JOURNAL HOMEPAGE

Full Terms \& Conditions of access and use can be found at http://hrmars.com/index.php/pages/detail/publication-ethics 


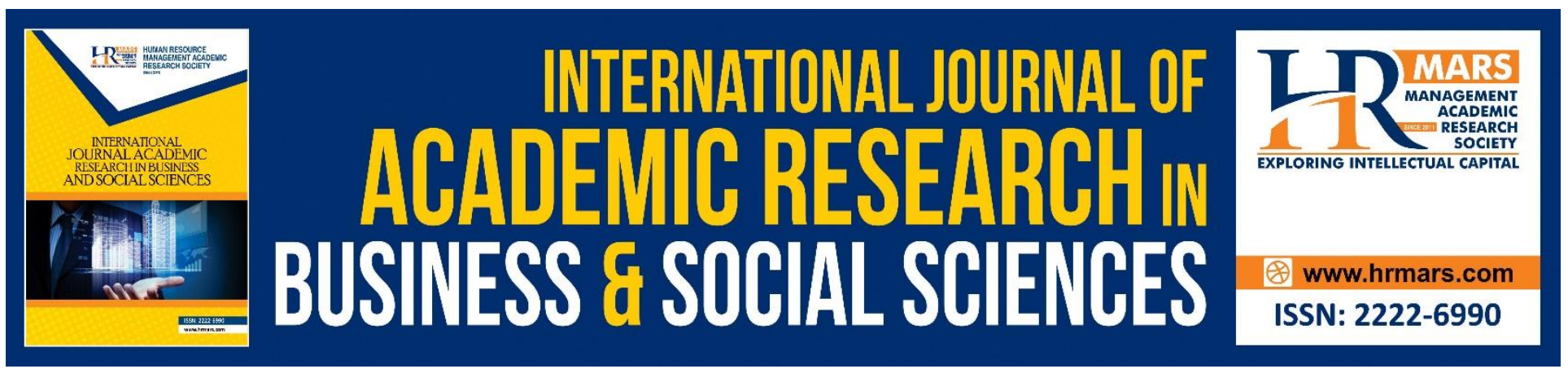

\title{
Regulating the Protection and Rehabilitation of Victims of Internet Child Pornography in Malaysia
}

\author{
Najwa Rosli \\ Lecturer, Faculty of Law, University of Malaya, 50603 Kuala Lumpur, Malaysia
}

Nabilah Hani Ahmad Zubaidi

Assistant Lecturer, Faculty of Law and International Relations, Universiti Sultan Zainal Abidin, 21300 Kuala Terengganu, Malaysia, and PhD Candidate at the School of Law, Aberystwyth University, SY23

3AS Wales, United Kingdom.

\section{Farah Nini Dusuki}

Senior Lecturer, Faculty of Law, University of Malaya, 50603 Kuala Lumpur, Malaysia

\begin{abstract}
Background: The conviction of Richard Huckle in London for 71 sexual offences that involved Malaysian child victims had caused uproar within the nation. 20,000 of indecent images of children, including those of which showed him committing child rape, were discovered on his computer during his arrest at Gatwick Airport in 2014. In response to this horrific event, a special task force was formed to review and propose stronger laws to protect children from sex predators. As a result, the Sexual Offences against Children Act 2017 (Act 792) was passed. Objective: This research paper seeks to evaluate the adequacy and practicality of the current Malaysian legal framework in providing a comprehensive protection for the victims of child pornography, which include issues on the viability of the penal sanctions and the access available for victims to support services. Findings are presented through library research, along with discussions with the relevant stakeholders where feasible. Conclusion: Although the laws are seemingly extensive and covered in various legislation such as the Sexual Offences against Children Act 2017, Criminal Procedure Code (Act 593), Penal Code (Act 574), and the Child Act 2001 (Act 611), it is found that there exist inconsistencies; both in terms of the definition and their purported applications that may hamper successful prosecution and effective enforcement.
\end{abstract}


INTERNATIONAL JOURNAL OF ACADEMIC RESEARCH IN BUSINESS AND SOCIAL SCIENCES

Vol. 9, No. 5, May, 2019, E-ISSN: 2222-6990 @ 2019 HRMARS

\section{Introduction}

In the last three years, cases involving individuals abusing children's images on the Internet within the Malaysian society has significantly increased. One widely reported case against at least 23 Malaysian children is the case of Richard Huckle, which became a national sensation in 2016, prompting the Malaysian authorities to propose new laws specifically on combatting child pornography (Huckle, 2016). The above is one case that has been detected thus far. Huckle was arrested by the British police at Gatwick Airport in 2014 and subsequently admitted to 71 sexual offences which included twelve counts of taking indecent photographs of children, one count of making indecent photographs, and one count of possession with a view to disturbing indecent photographs (R. v. Richard Huckle, 2016; BBC News, 2016). It was reported that investigators found more than 20,000 indecent pictures and videos of his sexual assaults on children, including those of which showed him committing child rape, to children aged between six months and 12 years of age, between the period of 2006 and 2014 (BBC News, 2016; Perimbanayagam, 2017; The Star, 2016).

Huckle shared the images and videos of his rapes and assaults on very young children from Vietnam, Cambodia and Malaysia in an encrypted web network via the dark web with paedophiles around the world, together with a paedophile manual titled "Paedophiles \& Poverty: Child Lover Guide" on how to abuse victims and evade detection (R. v. Richard, 2016; BBC News, 2016; The Star, 2016). He not only boasted of his endeavour to his peers, but he sought to profit from his crimes by attempting to sell footage to other abusers (BBC News, 2016). While presenting himself to his victims' families who make up of generally low-income small community from a Kuala Lumpur suburban as a respectable religious English teacher and philanthropist who could help them, Huckle was systematically abusing the children he claimed to care.

In response to this horrifying event, the Malaysian Prime Minister announced the establishment of a special task force headed by the de facto Minister of Law on August 2016 to review and propose stronger laws to protect children from sexual predators. As a result, in April 2017, the Sexual Offences against Children Act (hereinafter referred to as "SOAC 2017") was passed by the Parliament. The Sexual Crime and Children Division (D11) within the Royal Malaysian Police (hereinafter referred to as "RMP") Criminal Investigation Division was also assigned the task to provide psychiatric treatment and support to Huckle's young victims (The Straits Times, 2017; RMP, personal communication, 2017; UN Children's Fund, 2016). It is submitted that the conviction of Richard Huckle for 71 sexual offences that, among others, involved Malaysian child victims, was the main trigger of the SOAC 2017. The Minister, with the support of The Ministry of Women, Family and Community Development (hereinafter referred to as "MWFCD"), announced during the intense two days of debate on the SOAC 2017 in May that further amendments will be made to other legislation such as the Penal Code (Act 574), and the Child Act 2001 (Act 611) to complement the SOAC 2017 (Othman, 2017). The government and opposition stood together in unison to support whatever it took to pass the SOAC 2017, realizing that a law on the physical and digital spectrum of sexual offences against children was urgently needed. 
In light of the above, the first part of this paper will discuss the jurisprudential aspect on child pornography in the digital spectrum and the extent of the problem in Malaysia. As child pornography can be seen in several ways, this paper will focus on the depiction of sexually explicit images where an actual sexual assault has taken place against a child or a person appearing to be a child. The second part of this research will evaluate the adequacy of the Malaysian law in affording comprehensive protection for children against child pornography. The existing Malaysian legal framework together with international human rights documents such as that of the United Nation's Convention on the Rights of the Child (hereinafter referred to as the "CRC") and Optional Protocol on the Sale of Children, Child Prostitution and Child Pornography (hereinafter referred to as "the OPSC") will be critically examined to identify the strengths and weaknesses of the current legislation. In suggesting a workable solution to overcome the setbacks, reference will be made to the selected practice in other jurisdictions such as the United Kingdom, United States, Australia and Hong Kong.

\section{Methodology}

This research adopts a doctrinal approach. A library research was conducted to examine the legal literatures from the primary and secondary sources, which includes, but not limited to, the international human rights treaties, statutes, case-laws, extra-legal materials, articles, books and mass media reports. Semi-structured interviews were carried out face-to-face with the relevant stakeholders including the Sexual Crime and Children Division (D11) of the Royal Malaysia Police Criminal Investigation Division, Child Protection Unit of the Social Welfare Department under the Ministry of Women, Family, and Community Development, and two representatives from a child welfare NGO based in Kuala Lumpur (hereinafter referred to as "the NGO"). This particular NGO was selected because of its experience in working closely with abused children. It is also one of the main partners working with D11, RMP, in providing counselling to the child victims in Huckle's case.

\section{Results \& Discussion}

\section{Child Pornography and the Internet}

About two decades ago, the Internet has exacerbated child pornography by its existing architecture of providing anonymity to its users, increasing the volume of child pornography available, the efficiency with which it is disseminated, and the ease by which it can be accessed (Clough, 2015; Hornle, 2011; Wortley \& Smallbone, 2006). This creates opportunities for individuals to misuse ICT by creating harm, via sexually exploiting and abusing children. It is argued that the exponential growth of the Internet to be the reason behind an increase in prosecutions involving child pornography, what more with the widespread availability of home computers (Akdeniz, 2008; Ost, 2009). As the Internet becomes widely available and more pervasive, the number of child pornography prosecutions have increased (Wortley \& Smallbone, 2006), indicating that the Internet itself has become a dynamic avenue to channel, either in disseminating or assessing, child pornography images.

There is a concept of "double vulnerability" where Internet and child pornography comes together; as the Internet is shaky, architecture combined with vulnerability of children presents an attractive opportunity for abuse (Ost, 2009; Gillespie, 2011). In addition, children generally lack the skills to 
INTERNATIONAL JOURNAL OF ACADEMIC RESEARCH IN BUSINESS AND SOCIAL SCIENCES Vol. 9, No. 5, May, 2019, E-ISSN: 2222-6990 @ 2019 HRMARS

navigate through the Internet safely, making them an easy target for such abuse (The NGO, personal communication, 2017; Livingstone, 2009). There is also a worrying recent trend that abused children are getting younger and younger. It is estimated that almost 20 percent of pornography on the Internet involves the depictions of minors, and 90 percent of whom appear to be under the age of 12 years (Internet World Stats, 2017).

Though child pornography is not necessarily a 'high-tech' crime, the use of the Internet has radically transformed its incidence, and to a certain extent, its very nature (Gillespie, 2011). It is estimated that the Internet has penetrated to more than 68\% of the Malaysian population in 2016 (UN Children's Fund, 2016; Internet World Stats., 2017). This enhances the risks of abuse via the Internet, and this concept is strengthened by a statement from a Special Rapporteur of the OPSC who asserts that the probability of child pornography cases on the Internet is greater in countries with high rates of Internet access compared to countries with limited use of this technology (UN Commission on Human Rights, 2004).

\section{a) What constitute child pornography?}

What amounts to child pornography is said to be extraordinarily complex and elusive, as it differs according to location, religious, cultural and moral boundaries between societies (Ost, 2009; Cooray, 2017). It is therefore relevant to look at the standards established under international law, especially since Malaysia is state party to both the CRC and OPSC. The CRC and OPSC defines child pornography as any representation, by whatever means, of a child engaged in real or simulated explicit sexual activities, or any representation of the sexual parts of a child for primarily sexual purposes. These however, are international documents, which does not have direct impact on the regulation of child pornography in Malaysia unless adopted by the domestic law.

The CRC, which provides an international framework for determining the substantive content of child rights and adult responsibilities, identifies child pornography as a violation against children. Under Article 34, the CRC requires that countries, which are parties to it, implement measures to prevent the exploitative use of children in pornography. The Minister of Law was reported to have said that Malaysia is gradually taking steps to ensure that the nation's laws on child protection is in line with the CRC (Othman Said, 2017). However, inconsistencies in the existing legal framework might pose as hindrance to an effective adoption of the latter convention. Similarly, other international documents such as the European Union Council Framework Decision on combating the sexual exploitation of children and child pornography 2003 and the Budapest Convention on Cybercrime 2001 are clear examples of some international conventions addressing with child pornography (Cooray, 2017).

Child pornography can be seen in either a depiction of images where a child or a person appearing to be a child poses in a sexually explicit position, or the depiction of an actual sexual assault against a child (Akdeniz, 2008; Ost, 2009; Gillespie, 2011). Several authors on the subject went so far as to redefine child pornography as 'indecent photograph of a child', 'child image abuse', and 'child sexual abuse material' (Wortley \& Smallbone, 2006; Akdeniz, 2008; Ost, 2009). Prior to the SOAC 2017, there 
was no specific definition on child pornography in any legislation. The SOAC 2017, and the law as it is today, casts the net rather widely in defining what child pornography is. It is also a verbatim application of the definition provided in the CRC and OPSC. Section 4 of this Act defines child pornography to include images of a child, or anyone appearing to be a child, or realistic or graphic images of a child, or realistic or graphic images of anyone appearing to be a child, being engaged in a sexually explicit conduct. It is submitted that this wide definition may encompass cartoons, computer modified images or any images which appears to be a child, or has the participation of an actual child in in it.

\section{b) Child pornography: the extent of the problem in Malaysia}

Due to widespread Internet usage, Malaysian children are more exposed to the Internet today compared to ten or even five years ago. In a recent study by CyberSAFE Malaysia in cooperation with UN Children's Fund Malaysia and Digi Telecommunications, Internet users who are children make out over $50 \%$ of the total population who go online without being supervised (CyberSAFE, 2015). About two years ago, children's active participation in social media was marked mainly on the popular social media, Facebook, where it was revealed that children and young adults aged 13-24 years make up almost half of the Facebook users in the country (CyberSAFE, 2015). The survey also reported that $40 \%$ of the children do not know how to protect themselves online, with more than $40 \%$ realising the importance of online safety yet take little precautions (CyberSAFE, 2015). In the last one year, children are more active on social media networks such as BeeTalk and WeChat, engaging in dangerous and unsupervised relationship with strangers all around the world (Interview with the police, 7 September, 2017; Chow, 2017). Where children and adolescents were also reported to be surfing the Internet 19 hours a week on average, the number of hours being online is significantly increasing today, intensifying their potential exposure to pornography and other harmful materials (Bernama, 2010; Daud, 2016; Abdul Jalil, 2016). These facts are indeed worrying, as it reveals that more than $80 \%$ of parents in Malaysia have overlooked the threats of Internet child pornography (CyberSAFE, 2015). Cases such as Richard Huckle reflect how fragile the relationship between children and the Internet is, and how the Internet is capable of being misused and abused to sexually exploit children. Age of the child victim in Huckle's case for example, was as young as six months old (RMP, personal communication, 2017; the NGO, personal communication, 2017; BBC News, 2016)

It was reported that internationally, Malaysia ranked third for the possession of child pornographic materials, and number one in Asia (The Star, 2016). This proves that the existing legal mechanism is weak as it fails to bring offenders to court. In 2016 alone, there were numerous forums and seminars disseminating information on child pornography with the public, organised by R.AGE, the youth lifestyle section of The Star, NGOs, UN Children's Fund Malaysia, and Digi Telecommunications, indicating that it is indeed, a rising problem which the public and authorities are agonisingly becoming aware of.

The Sexual Crime and Children Division (D11) within the Royal Malaysia Police Criminal Investigation Division is responsible, among others, to provide psychiatric treatment and psycho-social support to child victims. Counselling of the child victims in Huckle's case was carried out by this division and 
several NGOs on a voluntary basis. It was revealed that they faced some challenges when it comes to parental support and cooperation from the victims themselves, who were either too young to appreciate the gravity of the crime or too traumatised by the experience that they fear exposing themselves to the authorities and journalists (RMP, personal communication, 2017; the NGO, personal communication, 2017). It was reported that 320 adults and 101 children in communities where Richard Huckle had gained accessed to were approached by the police, but the former are declining counselling and other help (The Straits Times, 2017). It could be a question of denial, pride, and shame, when the community leader himself went so far as to refuse any assistance whatsoever, and purportedly said that the matter should not be pursued further (The Straits Times, 2017). The NGO representatives also expressed their worry when they were not given permission to carry out a one-on-one counselling session with a victim by the victim's family (the NGO, personal communication, 2017). The authorities had no legal mandate to compel the child victims of pornography to be given support.

It was also reported that there is limited capacity and resources to provide the required follow-up upon the initial response, insufficient allocation of resources and manpower to put the system envisaged under the Child Act 2001 into practice. Limited number of trained child protectors under the Department of Social Welfare and broader coordination issues are the current and teething challenges in Malaysia to fully provide a comprehensive and an engaging support system to child victims (RMP, personal communication, 2017; the NGO, personal communication, 2017; and MWFCD, personal communication, 2017).

\section{Malaysia's current legal framework in addressing child pornography}

a) Penal sanctions on child pornography

This section will briefly discuss the penal sanctions related to child pornography. Prior to the passing of the SOAC 2017, child pornography was either mentioned implicitly or explicitly with limited specification. In fact, although the SOAC 2017 purports to be a law on sexual offences against children, it still has to be read together with other legislations such as the Child Act 2001, Communications and Multimedia Act 1998, Penal Code (Othman Said, 2017). In terms of court process and preparation of evidence, reference also need be made to the Evidence Act 1950 and Criminal Procedure Code. The term 'pornography' is non-existent in the following legislations, but rather references are made to the words 'obscene' and 'indecent' contents, which are the closest reference to pornography. In Malaysia, there is no distinction between adult and child pornography as both are deemed to be a crime.

Section 292 of the Penal Code (Act 574), section 4 of the Printing Presses and Publications Act 1984 (Act 301), and section 5 of the Film Censorship Act 2002 (Act 620), prohibit the production and dissemination of obscene materials through print medium, publications and films. Chapter 16 of the Penal Code penalises offences affecting inter alia, decency and morals, containing the closest pornography related provision to be read with section 292. The police are, however, more inclined to charge child pornography offenders under section 292 of the Penal Code. 
Section 292 of the Penal Code prohibits the production, selling, hiring, distribution, exhibition, import, taking part, advertise, offer or has in his possession any obscene book, pamphlet, paper, drawing, painting, representation or figure or any other obscene object. A person who commits an offence under this section shall be punished with imprisonment for a term which may extend to three years or with fine or with both. It is submitted that this section does not spell out the production of obscene materials in the digital sphere, but was used for Internet related offences because of the similarity in ingredients. Because the provisions do not mention the distribution of obscene objects online, applying them to online content is a large stretch. The following reported cases illustrate the way courts have dealt with online pornography using section 292 of the Penal Code in the last seven years.

It is unfortunate there is no case officially reported in the law journals as these cases were tried in subordinate courts, therefore, discovery of these cases relied heavily on mass media reports. In 2010, Shahrom Mahdi was charged under this provision for uploading pornographic pictures and disseminating them through six websites (Bernama, 2010; Abdul Jalil, 2015). Fila Shahida was also charged under the same section in October 2013 for recording an obscene video of a 15-year-old girl using her mobile phone (Borneo Post Online, 2013; Abdul Jalil, 2015). In both cases, they were sentenced to the payment fines by the court. In 2017, Sulaiman Mudakkundil was sentenced to an imprisonment of one year for the possession of about 100 pictures and videos of child pornography on his mobile phone (The Star, 2017). Unfortunately, though understandably, there were no follow up reports on the victims of these crimes whose identities were naturally protected in their best interests.

Provisions which specifically mention the word 'pornography' on the Internet before the SOAC 2017 are sections 211 and 233 of the Communications and Multimedia Act 1998 (hereinafter referred to as the "CMA 1998"), and Part I of the Malaysian Communications and Multimedia Content Code (hereinafter referred to as "Content Code"), targeted especially to Internet service providers (hereinafter referred to as "ISP"). However, as at August 2017, it is puzzling why there has yet to be any pornography cases that have been tried under the CMA 1998. It is therefore submitted that the main difficulty lies in not having legal definition on what constitute pornography or child pornography. Section 211 of the CMA 1998 prohibits the production of offensive content online with stricter punishment compared to the Penal Code. A person who contravenes this section commits an offence and shall, on conviction, be liable to a fine not exceeding RM50,000 or to imprisonment for a term not exceeding one year or to both and shall also be liable to a further fine of RM1,000 for every day or part of a day during which the offence is continued after conviction. Section 233 makes it an offence for improper use of network facilities or network service for obscene materials. A person who commits an offence under this section shall, on conviction, be liable to a fine not exceeding RM50,000 or to imprisonment for a term not exceeding one year or to both and shall also be liable to a further fine of RM1,000 for every day during which the offence is continued after conviction. It is suggested that the monetary penalties in the CMA 1998 makes conviction an 'expensive' offence, which is undoubtedly for preventive and deterrent purposes. 
Additionally, the Content Code makes it illegal to sell or possess pornographic material, which makes a person liable to prosecution with a fine of up to RM50,000 or a one year imprisonment, or both. Targeted exclusively to ISP providers and not the public, compliance by the former to the Content Code is, surprisingly, voluntary, per section 98(1) of the CMA 1998. The Content Code is therefore merely a set of guidelines and procedures for good practice and standards for content dissemination, with no punishable powers, hence contributed to inconsistencies in its application (Azmi, 2004). Such developments arguably create easy access to pornographic materials on the Internet today, signifying a weakness in the country's ability to reduce the availability of online child pornography.

It is gratifying to note that the SOAC 2017 covers rather extensively on sexual offences against children including child pornography. The term 'child pornography' is clearly defined in section 4. It is submitted that the definition is all-embracing that covers any kind of representation in any form of a child or person appearing to be a child or even realistic or graphic images of a child engaged in sexual explicit conduct. The term 'sexually explicit conduct' is further clarified in the same section; where it is referred to as the actual or simulated sexual intercourse, lewd acts, bestiality, masturbation, sadistic or masochistic abuse in a sexual context, exhibition for sexual purpose of the genital, buttock, breast, pubic area or anus, and the use of instrument for lewd acts.

Part I, and particularly Section 5 of the SOAC 2017 imposes a maximum jail sentence of 30 years, and the reception of not less than six strokes of the whip upon conviction, for the making, producing, directing the making or production of child pornography. Section 6 penalizes the making or production of child pornography with imprisonment not exceeding ten years and whipping. Section 7 imposes a maximum imprisonment term not more than 20 years and whipping not less than 5 strokes for using a child in the making or production of child pornography. Exchanging or selling child pornography is addressed in sections 8 and 9, penalizing offenders with a maximum jail sentence of 15 years and whipping. Anyone who is convicted under section 10 for assessing child pornography shall be liable to imprisonment for a term not more than five years and RM10,000 fine. It further inserts provisions to fight child grooming to identify sexual predators who are preying on the young via the Internet and through the different online chat apps on Part II of the Act, introducing a maximum jail time of 5 years and whipping for grooming, and a maximum jail sentence of 10 years and whipping for any meetings following the grooming.

Part IV of the Act is specifically on the offence relating to any sexual assault to child, either it is done physically or non-physically, with a maximum jail sentence of 20 years and whipping for the former, and 10 years and whipping for the latter. Another significant provision is section 16 . The section imposes additional punishment of imprisonment not more than 5 years and mandatory whipping not less than 2 strokes apart from the initial punishment for the offender who is in a relationship of a trust with the child such as parent, teacher, and guardian.

Section 26 furthermore provides for rehabilitative counselling for offenders of any sexual offences against a child within the Act or other related offences within the period of his detention, but does not mention any orders on rehabilitative counselling for child victims. It is submitted that as much as 
INTERNATIONAL JOURNAL OF ACADEMIC RESEARCH IN BUSINESS AND SOCIAL SCIENCES

Vol. 9, No. 5, May, 2019, E-ISSN: 2222-6990 @ 2019 HRMARS

the SOAC 2017 serves to punish and give rehabilitative support to offenders, it fails to address the needs of the child victims to support programs contained in other related legislations such as rehabilitation, counselling and compensation.

\section{b) Child pornography victims' access to rehabilitation \& compensation}

Apart from postulating penal sanctions, another vital aspect in protecting children from sexual exploitation in the form of child pornography is their welfare support. Various researches have shown the adverse effects of child pornography on the victims' mental health, emotional and physical development. Physically, victims suffer pain and/or injury such as genital bruising, lacerations and cuts, headaches, loss of appetite and insomnia (Wortley \& Smallbone, 2006; Rogers, 2016). Other detrimental effects are psychological distress, the feeling of worthlessness, emotional isolation, anxiety, fear and guilt (Rogers, 2016; Llyod \& Selby, 2015). As a result, victims often engage in selfdestructive behavior such as depression, substance abuse, suicide and turning into prostitution (Klain, Davies \& Hicks, 2001).

In addition, the continuous dissemination and circulation of the abusive images may cause revictimization (Rothman, 2011). The victims' mindfulness and realization of the fact that thousands of individuals may have or might be seeing and possessing the images of them being sexually abused may inflict profound and life-lasting trauma (Cassell, Marsh \& Christiansen, 2016). Owing to these negative impacts to the child victims, Article 9 of the OPSC obligates the state parties to take feasible measures in providing appropriate assistance to the victims such as rehabilitation programs and the access to compensation.

\section{c) Victims' welfare support in Malaysia}

In Malaysia, the provisions on the child welfare support are codified in the Child Act 2001 (hereinafter referred to as "the CA 2001") that lists the rescue and support procedures. Generally, the CA 2001 categorises children into different groups depending on their needs and the required intervention measures. However, for the victims of child pornography, there exist intricacies in categorizing them into the relevant groups; whether they ought to be categorized as 'children in need of care and protection' or 'children in need of protection and rehabilitation'? Both categories are governed by different provisions comprising of different rescue procedures and protective institutions.

To begin with, it appears logical enough to categories the victims within the category of 'children in need of care and protection' under Part V of the CA 2001, as the term 'pornography' is among the many sub-categories explicitly provided in section 17(2). It stipulates that a child be sexually abused if, inter alia, he or she has taken part as a participant or observer in any sexual activities for the purpose of pornography. Unfortunately, the scope appears to be limited, as to qualify for the protection under the said category, the victims must be those who have been sexually abused within a family, guardian and relative setting. Section 17(1) confines the protection to children:

(i) Who have been sexually abused by a parent, guardian or relative?

(ii) Who are in substantial risk of being abused by a parent, guardian or relative? 
(iii) Whom the parent, guardian or relative have the knowledge that the children have been sexually abused but has not or unlikely to protect them against harm; or

(iv) Whom the parent, guardian or relative have the knowledge that the children are in a substantial risk of being been sexually abused but has not or unlikely to protect them against the harm.

This provision effectively excludes protection to children who have been sexually abused or are at risk of sexual abuse by other persons than his parent, guardian or relative of whom have no knowledge of the abuse. This gap may however be filled by invoking protection under part VI of the CA 2001 which provide situations where children are categorized to be in need of protection and rehabilitation'. Children who are involved in child pornography suits within the sub-category of section 38(a) that provides "a child who is being induced to perform any sexual act, or is in any physical or social environment which may lead to the performance of such act".

The following flowcharts and table compare and contrast the difference between rescue procedures and the related children institution of both categories: 
INTERNATIONAL JOURNAL OF ACADEMIC RESEARCH IN BUSINESS AND SOCIAL SCIENCES Vol. 9, No. 5, May, 2019, E-ISSN: 2222-6990 @ 2019 HRMARS

\section{Chart 1: Rescue procedures for 'children in need of care and protection'}

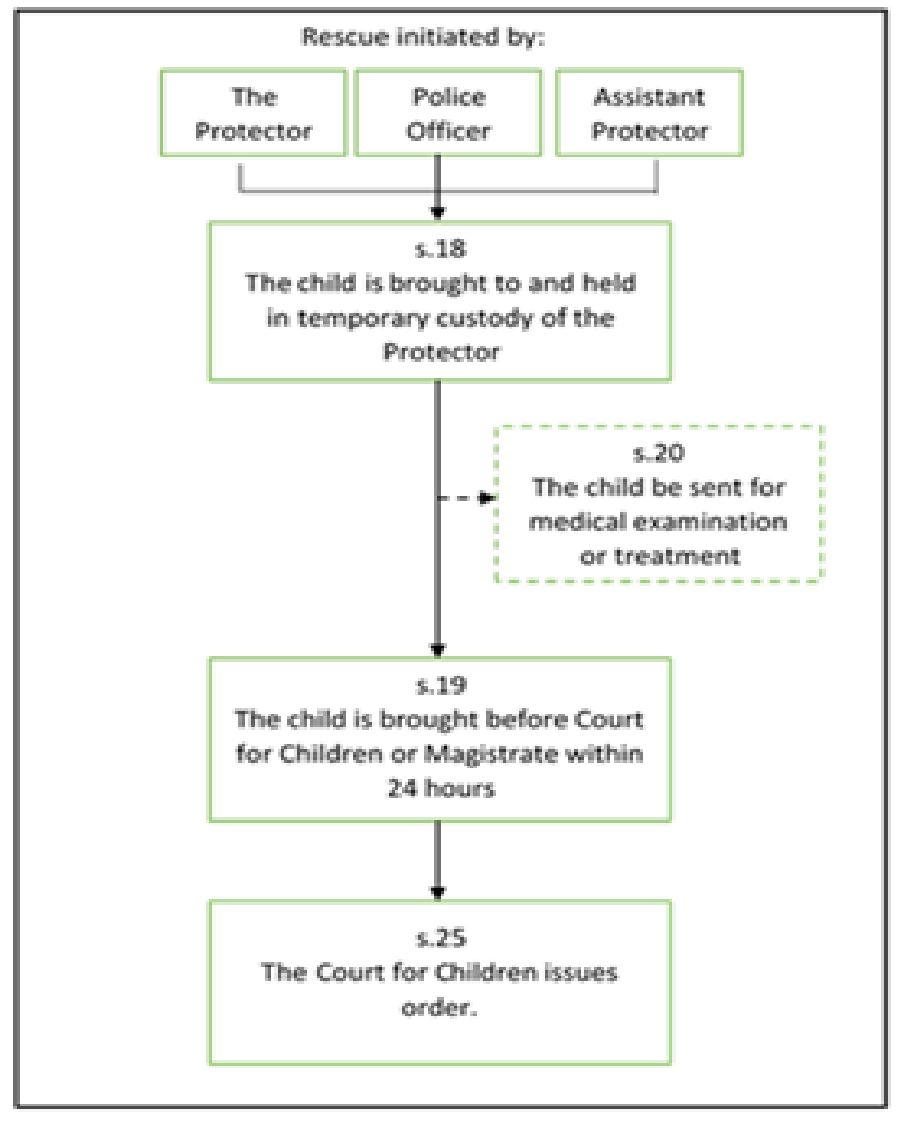


INTERNATIONAL JOURNAL OF ACADEMIC RESEARCH IN BUSINESS AND SOCIAL SCIENCES Vol. 9, No. 5, May, 2019, E-ISSN: 2222-6990 @ 2019 HRMARS

\section{Chart 2: Rescue procedures for 'children in need of protection and rehabilitation'}

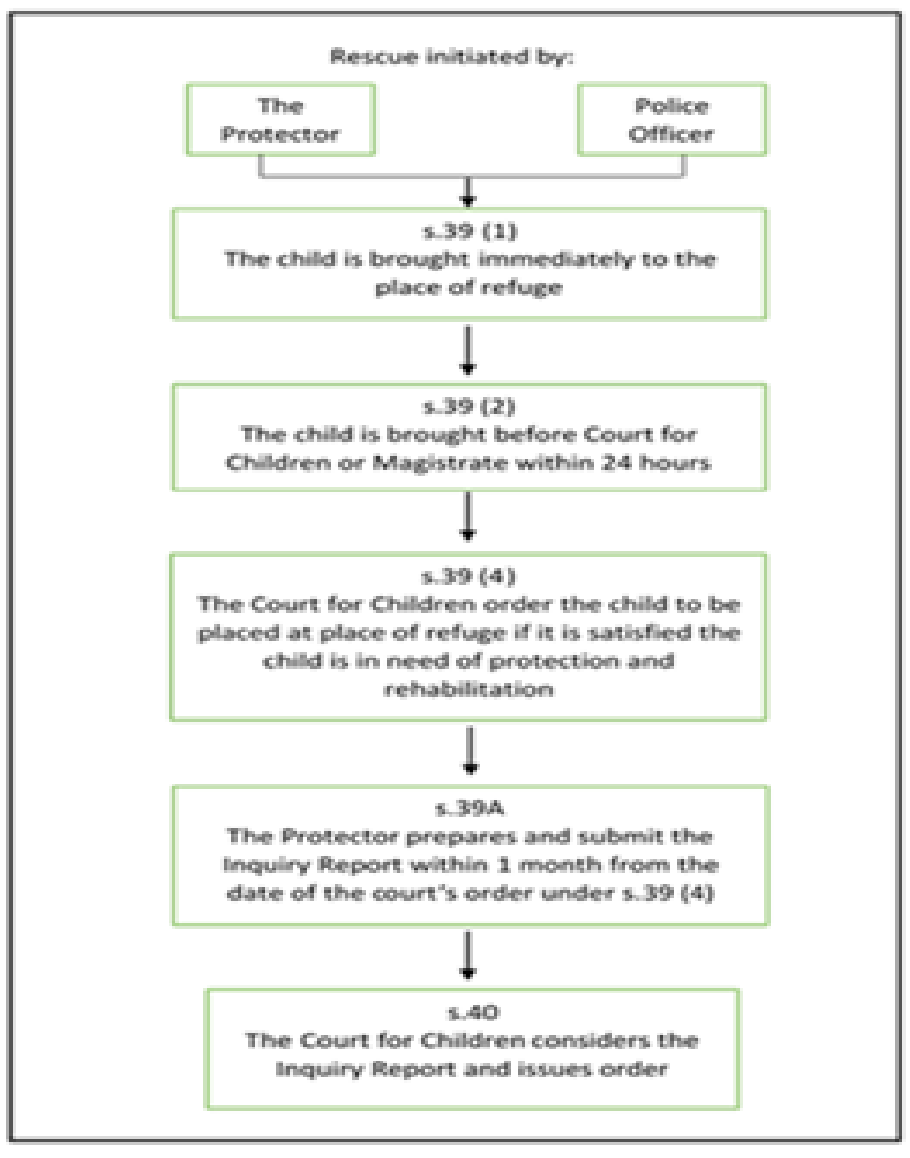


INTERNATIONAL JOURNAL OF ACADEMIC RESEARCH IN BUSINESS AND SOCIAL SCIENCES

Vol. 9, No. 5, May, 2019, E-ISSN: 2222-6990 @ 2019 HRMARS

Table 1: The Comparison between Part V and Part VI of the CA 2001 on the Power of the Court and Children Institution.

\begin{tabular}{|c|c|c|c|}
\hline No. & & $\begin{array}{c}\text { Part V CA } 2001 \\
\text { Children in need of care and } \\
\text { protection }\end{array}$ & $\begin{array}{c}\text { Part VI CA } 2001 \\
\text { Children in need of protection and } \\
\text { rehabilitation }\end{array}$ \\
\hline 1. & $\begin{array}{l}\text { Power of } \\
\text { the court }\end{array}$ & $\begin{array}{l}\text { Section } 30 \\
\text { The Court for Children may order: } \\
\text { i. the parent or guardian to } \\
\text { execute a bond to exercise } \\
\text { proper care and } \\
\text { guardianship for a period } \\
\text { specified by the Court; } \\
\text { ii. placing the child in the } \\
\text { custody of a fit and proper } \\
\text { person for a period specified } \\
\text { by the Court; } \\
\text { iii. placing the child in the care, } \\
\text { custody and control of a } \\
\text { foster parent found to be } \\
\text { suitable for a period of } 2 \\
\text { years or until he attains the } \\
\text { age of } 18 \text { years old, } \\
\text { whichever shorter; } \\
\text { iv. placing the child in a centre } \\
\text { for a period of three years } \\
\text { from the date of the order or } \\
\text { until he attains the age of } 18 \\
\text { years old, whichever shorter; } \\
\text { or } \\
\text { placing the child in a place of } \\
\text { safety for a period of three } \\
\text { years from the date of the } \\
\text { order or until he attains the } \\
\text { age of } 18 \text { years old, } \\
\text { whichever shorter. }\end{array}$ & $\begin{array}{l}\text { Section } 40 \\
\text { After deliberating the Inquiry } \\
\text { Report, the Court for Children may } \\
\text { order: } \\
\text { i. requiring the parent or } \\
\text { guardian of the child to } \\
\text { execute a bond, with or } \\
\text { without sureties for period } \\
\text { not exceeding three years } \\
\text { for the proper care and } \\
\text { guardianship of the child; } \\
\text { ii. placing the child for a period } \\
\text { not exceeding three years in } \\
\text { care of a fit and proper } \\
\text { person; } \\
\text { iii. placing the child under the } \\
\text { supervision of a Social } \\
\text { Welfare Officer for a period } \\
\text { not exceeding three years; } \\
\text { iv. placing the child in a centre } \\
\text { for a period not exceeding } \\
\text { three years; or } \\
\text { v. placing the child in a place } \\
\text { of refuge for a period of } \\
\text { three years. }\end{array}$ \\
\hline 2. & $\begin{array}{l}\text { Children } \\
\text { institution }\end{array}$ & 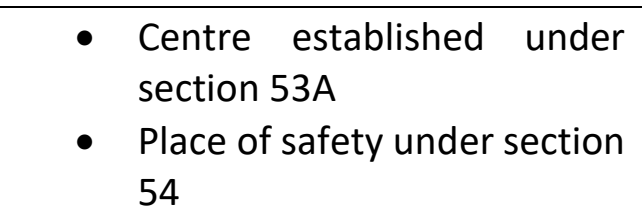 & 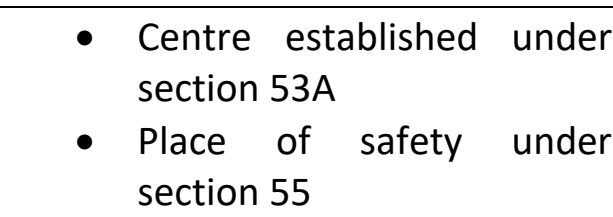 \\
\hline
\end{tabular}


The latest amendment to the CA 2001 in 2016 reinforces parental responsibilities towards children and empowers the right of children not to be deprived of family-based care unnecessarily. For that reason, Sections 30 and 40 of the CA 2001 offers the option to place children in alternative care as the last resort. Despite that, and whilst acknowledging that institutionalization is not always supportive of the best interests of children, it is submitted that placing the victims in children institution in certain circumstances may be necessary for their own interests, for instance, in cases where the victim becomes pregnant as the result of the abuse. Pregnancy out of wedlock is generally scorned upon and stigmatized in the eyes of the society, leaving the victims to be potentially discriminated and ousted by their own family and community.

As pointed earlier, there are different institutions established for the two different categories of children in need. For instance, 'children in need of care and protection' may be sent to the place of safety established under section 54 of the CA 2001. This institution is established not only to shelter child sexual abuse victims per se, but also other children enlisted in section 17 of the CA 2001, including that of abandoned and street children. Accordingly, the facilities and programs may not be proportionate and effective for the full physical and psychological recovery of child pornography victims. They are more suitably placed in a place of refuge established under section 55 for 'children in need of protection and rehabilitation'. Such an institution is established and equipped with programs specially designed for children who are victims of sexual exploitation. For that reason, it is submitted that child pornography victims, irrespective of whether the abuse took place within the family domain or beyond, ought to be categorized as 'children in need of protection and rehabilitation'. However, to ensure consistent and efficient enforcement, it is proposed that a specific regulation or administrative protocol is designed for the optimal protection and reintegration of children.

Interestingly, whether the victim is ordered to be in the custody of family, fit and proper person or children institution, the law grants power to the court to impose such conditions and directions deemed fit to the parents or guardian such as attending interactive workshops (under section $30(8)$, 40 (12) of the CA 2001). Hence, this is significant to ensure continuous parental support and cooperation.

Regrettably, various research have established that although it appears to be more suitable for these children to be sent to such institution upon incidents of sexual exploitation, the rehabilitative and reintegration efforts are not optimally provided. For example, rather than preparing them for having other required competencies, these children are mostly trained to be equipped with domestic skills (Yahaya et al., 2001; Yahaya, Hashim \& Abd Wahab, 2010; Saim et. al, 2013). It remains to be seen whether the new amendments will serve the plight of these children better. 


\section{d) Child victim(s) compensation}

The rights of a crime victim, especially from child pornography, who has suffered harm, including physical or mental injury, emotional anguish and economic loss to legal remedy are well recognized under the international law. The remedy encompasses many different forms like restitution, compensation and other necessary assistance (UN General Assembly, 1985). As noted earlier, the right of child victim(s) who have been sexually abused and exploited to claim for compensation is enshrined in Article 9 of the OPSC (UNHR, 2000).

Within the Malaysian context, the provision relating to the access of child victims to compensation is silent in the SOAC 2017 and the CA 2001. However, reference can be made to section 426 (1A) of the Criminal Procedure Code (hereinafter referred to as "the CPC"). According to the section, a victim of a convicted crime may be compensated for the injury resulting from the offence committed. The said injury includes the victim's personal injury, damage to his character, and the loss of income or property. The compensation can only be awarded by the court before which the offender is convicted. In quantifying the compensation, the court shall, as guided in section $426(1 \mathrm{C})$, consider various factors such as the nature of the offence, the expenses incurred by the victim, and the ability of the convicted accused to pay.

Even though section 426 of the CPC does offer the avenues for victims to claim compensation, the actual application of this section is reported to be rather sporadic (Wook, 2011). Moreover, the application of this section raises the following concerns. First, the compensation is not guaranteed as it must be preceded with the conviction of the perpetrator and the application by the prosecutor to the court (section $426(1 \mathrm{~A}) \mathrm{CPC}$ ). At this point, reference can be made to the practice in the United States. By virtue of $\S 2259$ of 18 U.S. Code, it is mandatory for the court to issue the order of restitution that directs the offender to pay the full amount of losses suffered by the child sexual exploitation and abuse victim(s). The amount shall include the expenses on medical services relating to physical, psychiatric, or psychological care, physical and occupational therapy or rehabilitation, transportation, child care expenses, as well as other costs and losses incurred resulting from the offence ( $\$ 2259$ (B)(3), 18 U.S. Code). Besides that, contrasting to our section 426 (1C) of the CPC, the ability of the offender to pay is irrelevant and could not be the grounds of refusing the award ( $\$ 2259$ (B) (4), 18 U.S. Code).

Secondly, as mentioned previously, section 426(1A) of the CPC requires the conviction of the offender and furthermore, the court may hold another inquiry in determining the amount of compensation (section 426 (1D), the CPC). The implication of this lengthy procedure is that the child victim may be called again at the inquiry stage to testify. It has been highlighted by the Committee of the CRC that repeated interviews may pose traumatic effects, resulting in the refusal of the victims to cooperate or facing despair at some point during the process (ECPAT, 2017). This was also observed by ECPAT Belgium and ECPAT Germany in their report to ECPAT International in "Access to Justice and Right to Remedies for Child Victims of Sexual Exploitation Research Project" (ECPAT, 2017). 
The possible solution to the aforementioned implication is by establishing a direct access to a state fund where the procedures will be purely administrative. For example, the establishment of the Criminal Injuries Compensation Scheme in England, Scotland and Wales, the Victims Assistant Scheme in New South Wales Australia, and the Criminal and Law Enforcement Injuries Compensation Scheme (CLEIC) in Hong Kong. Moreover, the State fund would be the best alternative in assuring financial assistance for the victims to undergo physical and mental rehabilitation services in the event compensation by perpetrator is infeasible (ECPAT, 2017).

\section{Conclusion}

Based on the above findings, it is submitted that the SOAC 2017 is a significant milestone in the Malaysian law in protecting children against child pornography. Apart from clarifying child pornography, the Act correspondingly provide a comprehensive provision to incriminate not only the possession, exchange, production, distribution, publication and access to child pornography, but also to criminalise sexual grooming and assault that may lead to the production of child pornography. It is however important to note that establishing adequate penal sanctions alone is insufficient. As provided in Article 9 of the OPSC, the welfare of the child victims should be given equal attention. There is a pressing need for constructive legal provisions to regulate the required overall welfare protection and rehabilitation of victims of Internet child pornography in Malaysia. Although intervention procedures in Part VI of the CA 2001 could be applied by the enforcement team in rescuing the victims, to ensure its effectiveness, comprehensive and well-coordinated action and cooperation from both the state and family institutions are required. Apart from protection and rehabilitation, it is imperative that child victims should be given direct accessibility for compensation either by way of establishing a state-fund mechanism or via mandatory court order. It is also recommended that preventive measures which incorporate holistic support from the government, civil societies and private sectors be established. In the final analysis, it is crucial that good online practices on child sexual abuse and Internet child pornography be promulgated and disseminated. This is to spread greater awareness on the issues, and to educate both parents and children alike that child pornography is indeed a grotesque and intolerable crime, be it in the offline or online realm.

\section{Corresponding Author}

Najwa Rosli, Faculty of Law, University of Malaya, 50603 Kuala Lumpur, Malaysia.

Email: najwarosli@um.edu.my

\section{References}

Royal Malaysia Police (2017). Interview with an officer from D11, Royal Malaysia Police on 7 September.

Ministry of Women, Family, and Community Development (2017). Interview with an officer from the Child Protection Unit, Department of Social Welfare, Ministry of Women, Family, and Community Development on 24 August.

A child welfare NGO based in Kuala Lumpur (2017). Interview with two representatives from this NGO on 18 August. 
INTERNATIONAL JOURNAL OF ACADEMIC RESEARCH IN BUSINESS AND SOCIAL SCIENCES

Vol. 9, No. 5, May, 2019, E-ISSN: 2222-6990 @ 2019 HRMARS

Jalil, A. J. (2016). Combating Child Pornography in Digital Era: Is Malaysian Law Adequate to Meet the Digital Challenge? Pertanika J. Soc. Sci. \& Hum. 23 (S): $137-152$.

Akdeniz, Y. (2008). Internet child pornography and the law: National and International Responses. Aldershot: Ashgate.

Azmi, I. M. (2004). Content Regulation in Malaysia: Unleashing Missiles on Dangerous Websites, Journal of Information Law \& Technology 3. Retrieved from

http://www2.warwick.ac.uk/fac/soc/law/elj/jilt/2004_3/azmi/\#_edn5\#_edn5, accessed July 2017.

BBC News (2016), June 6. Briton Richard Huckle Jailed for Malaysia Sex Abuse. Available online at http://www.bbc.co.uk/news/uk-36458472, accessed July 2017.

Bernama (2010), June 4. Internet Porn: Guard Gets Six Months Jail. Available online at http://www.namnewsnetwork.org/v3/read.php?id=MTlyNTk5, accessed July 2017.

Borneo Post Online (2013), October 12. Fined for Producing Obscene Video, available online at http://www.theborneopost.com/2013/10/12/fined-for-producing-obscene-video/, accessed on 13 November 2015.

Cassell, P.G., J.R. Marsh, and J.M. Christiansen (2016). Not Just "Kiddie Porn": The Significant Harms from Child Pornography Possession in Hessick, C. B. (Ed.), Refining Child Pornography Law Crime, Language, and Social Consequences (pp. 165-186). Ann Arbor: University of Michigan Press.

Chow, S. (2017). Sex Predators in Malaysia Using Apps to Prey on Underage Girls. The Star. Available online at http://www.asiaone.com/singapore/sex-predators-malaysia-using-apps-preyunderage-girls

Clough, J. (2015). Principles of Cybercrime. $2^{\text {nd }}$ Edi., United Kingdom: Cambridge University Press.

Cooray, M. (2017). Child pornography on the internet: When the "images" matter. International Journal for Studies on Children, Women, Elderly and Disabled, Vol. 1. ISSN 0128-309X

CyberSAFE Survey Report (2015). Digi CyberSAFE in Schools. Report available online at https://www.malaysianwireless.com/wp-content/uploads/2015/11/Digi-CyberSAFE-inSchools-2015-survey-report.pdf, accessed July 2017.

Daud, M. (2016). A legal analysis of digital expression and online content regulation in Malaysia, unpublished PhD thesis, International Islamic University Malaysia.

ECPAT. (2017). Barriers to Compensation for Child Victims of Sexual Exploitation. Thailand: ECPAT International.

Gillespie, A. (2011). Child pornography law and policy. Routledge, Taylor \& Francis Group: A Glasshouse book.

Hornle, J. (2011). Countering the dangers of online pornography - shrewd regulation of lewd content. European Journal of Law and Technology, Vol. 2, No. 1. Queen Mary University of London, School of Law Legal Studies Research Paper No. 65/2010. Internet World Stats (2017). Malaysia. Available online at http://www.internetworldstats.com/asia.htm\#my., accessed July 2017.

Klain, E. J., H. J. Davies, and \& M. A. Hicks (2001). Child Pornography: The Criminal-Justice-System Response. Alexandria, VA: National Centre for Missing \& Exploited Children.

Livingstone, S. M. (2009). Children and the Internet. Cambridge: Cambridge: Polity. 
INTERNATIONAL JOURNAL OF ACADEMIC RESEARCH IN BUSINESS AND SOCIAL SCIENCES

Vol. 9, No. 5, May, 2019, E-ISSN: 2222-6990 @ 2019 HRMARS

Lloyd, M., and H. Selby (2015). Full Evidence Overview Report 2: Sexual Assault and Child Sexual Exploitation (Publication). Michael Lloyd Research (MLR) \& Office of the Police and Crime Commissioner for Merseyside (OPCCM).

Ministry of Women, Family and Community Development and UN Children's Fund (UNICEF) Malaysia (2013). Child Protection System in Malaysia: Analysis of the System for Prevention and Response to Abuse, Violence and Exploitation against Children. Kuala Lumpur.

Ministry of Women, Family and Community Development (2010). November 4-10. Child Protection and Child Welfare Services in Malaysia. Beijing High Level Meeting.

Ost, S. (2009). Child Pornography and Sexual Grooming. Cambridge University Press: Cambridge Studies in Law and Society.

Said, O. A. (2017), April 16. Making the Impossible Possible. The Star. Available online at http://www.thestar.com.my/news/nation/2017/04/16/making-the-impossible-possible-

after-much-hard-work-and-brainstorming-the-sexual-offences-against-ch/, accessed July 2017.

Perimbanayagam, K. (2017), September 25. A Paedophile's Diary: Richard Huckle Kept Account of His Grotesque Act. The Straits Times. Available online at https://www.nst.com.my/news/nation/2017/09/284002/paedophiles-diary-richard-hucklekept-account-his-grotesque-acts, accessed July 2017.

Richard, H. R. V. (2016). London Central Criminal Court (Old Bailey), Case no.: T20157046, available online at http://www.thelawpages.com/court-cases/Richard-Huckle-17648-1.law

Rogers, A. (2016). The Dignitary Harm of Child Pornography-From Producers to Possessors in Hessick, C. B. (Ed.), Refining Child Pornography Law Crime, Language, and Social Consequences (pp. 165-186). Ann Arbor: University of Michigan Press.

Rothman, J. (2011). Getting What They Are Owed: Restitution Fees for Victims Of Child Pornography. Cardozo Journal of Law \& Gender, 17, 333-357.

Saim, N. J., Dufăker, M., Eriksson, M. and Ghazinour, M. (2013). Listen to the Voices of Unwed Teenage Mothers in Malaysian Shelter Homes: An Explorative Study. Global Journal of Health Science, 5(5). doi:10.5539/gjhs.v5n5p20

Sivanandam H. (2016). Malaysia ranks third in Asean countries for child porn violations. The Star. Available online at https://www.thestar.com.my/news/nation/2016/06/26/malaysia-ranksthird-in-the-world-for-child-porn-violations/\#JYcYWPLdfxjX3027.99, accessed July 2017.

The Star. (2016), June 6. Paedophile Richard Huckle Who Jailed Malaysian Children Jailed for Life. Available online at http://www.thestar.com.my/news/nation/2016/06/06/paedophilerichard-huckle-who-abused-malaysian-children-jailed-for-life/, accessed July 2017.

The Star. (2017), January 17. Man Jailed a Year for Having Child Porn. Retrieved at http://www.thestar.com.my/news/nation/2017/01/17/man-jailed-a-year-forhaving-childporn/, accessed July 2017.

The Straits Times. (2017), January 15. Malaysian Communities in Denial After British Paedophile Richard Huckle Sentenced: Police. Available online at http://www.straitstimes.com/asia/seasia/malaysian-communities-in-denial-after-british-paedophile-richard-huckle-sentenced, accessed July 2017. 
INTERNATIONAL JOURNAL OF ACADEMIC RESEARCH IN BUSINESS AND SOCIAL SCIENCES

Vol. 9, No. 5, May, 2019, E-ISSN: 2222-6990 @ 2019 HRMARS

UN Commission on Human Rights (UNCHR) (2004). Report of the Special Rapporteur on the sale of children, child prostitution and child pornography, submitted by Special Rapporteur Juan Miguel Petit, 23 December, available online at http://www.refworld.org/docid/42d66e480.html, accessed July 2017.

UN General Assembly (1985). Declaration of Basic Principles of Justice for Victims of Crime and Abuse of Power. [Resolution / adopted by the General Assembly, 29 November 1985, A/RES/40/34]

UN Children's Fund (UNICEF) (2016). Child Protection in the digital age: National responses to online sexual abuse and exploitation in ASEAN Member States. Strengthening Child Protection Systems Series, No. 6, Bangkok: UNICEF EAPRO.

United Nations Human Rights (UNHR) (2000). Office of the High Commissioner for Human Rights. Optional Protocol to the Convention on the Rights of the Child on the sale of children, child prostitution and child pornography (OPSC, Malaysia acceded on 12 April 2012). Available online at http://www.ohchr.org/Documents/Professionallnterest/crc-sale.pdf, accessed July 2017.

Wook, I. (2011). Compensation Order Provision by Criminal Courts in Malaysia and the United Kingdom. Malayan Law Journal Articles. [2010] 2 MU li.

Wortley, R., and S. Smallbone. (2006). Child Pornography on the Internet: Problem-Oriented Guides for Police: Problem-Specific Guides Series: No. 41. PsycEXTRA Dataset. doi:10.1037/e517392006-001.

Yahaya, A., A. Rahman, M. Anuar, A.R Hamdan, and Y. Boon (2001). Program Pemulihan Akhlak Wanita: Sejauhmanakah Keberkesanan pusat perlindungan Wanita Membantu Proses Pemulihan? (Women's Moral Rehabilitation Centres: how far do these centres help the rehabilitation process?) Universiti Teknologi Malaysia 1-9, available online at http://eprints.utm.my/10408/1/2.pdf., accessed on 14 July 2017.

Yahaya, A., S. Hashim, J. \& Wahab, A. (2010). Keberkesanan Program-Program Pemulihan Tingkah laku Di Taman Seri Putri Batu Gajah Dan Kompleks Dar-Assa'adah. Universiti Teknologi Malaysia Institutional Repository (Unpublished), available at http://eprints.utm.my/10617/., accessed on 14 July 2017. 